\title{
Husbandry, Productivity and Producers Trait Preference of Goats in North Western Lowlands of Ethiopia
}

\author{
Tilahun Debela', Mengistu Urge'2, Getnet Assefa ${ }^{3}$, Zeleke Mekuriaw ${ }^{4}$ \\ ${ }^{1}$ Pawe Agriculture Research Center, Pawe, Ethiopia \\ ${ }^{2}$ School of Animal and Rangeland Sciences, Haramaya University, Dire Dawa, Ethiopia \\ ${ }^{3}$ Ethiopian Agricultural Research Institute, Addis Ababa, Ethiopia \\ ${ }^{4}$ International Livestock Research Institute, Addis Ababa, Ethiopia \\ Email: tiladeb1953@gmail.com
}

How to cite this paper: Debela, T., Urge, M., Assefa, G. and Mekuriaw, Z. (2020) Husbandry, Productivity and Producers Trait Preference of Goats in North Western Lowlands of Ethiopia. Open Journal of Animal Sciences, 10, 313-335.

https://doi.org/10.4236/ojas.2020.102019

Received: March 22, 2020

Accepted: April 27, 2020

Published: April 30, 2020

Copyright $\odot 2020$ by author(s) and Scientific Research Publishing Inc. This work is licensed under the Creative Commons Attribution International License (CC BY 4.0).

http://creativecommons.org/licenses/by/4.0/

(c) (i) Open Access

\begin{abstract}
A survey was conducted in Agalo Meti, Bambasi and Mandura districts of Kamashi, Assosa and Metekel zones of Benishangul-Gumuz Regional State, respectively. The aim of the study was to assess production characteristics, productive performances and producer's traits preference of goats. A total of 177 households who have goat flock and experience in goat production were purposively selected. Data was collected through respondent interviews using structured questionnaire, focus group discussions, key informant interviews and field visit. Data was analyzed using SPSS software and reported using descriptive statistics. Indices were used to present ranking. Farming is characterized by mixed-crop livestock production system and livestock are kept under traditional extensive management system. Greater number of goats than other livestock species were owned in the area. The indigenous goats reared in the area include Arab, Felata and Gumuz. The mean goat flock size per household was $9.81 \pm 1.08,8.31 \pm 1.16$ and $8.71 \pm 0.88$ in Agalo Meti, Bambasi and Mandura district, respectively. Goats were primarily kept for generating income (indices $=0.43$ ), followed by saving/insurance $(0.34)$, and meat for home consumption (0.18). About $58 \%$ of the producers sell goat skins, whereas $(42 \%)$ did not-sold through the formal market chain. Natural pasture and indigenous browse species were the major feed resources. About $89.3 \%$ of the respondents housed their goats in a well-shaded separately constructed house. The herding practices of goats include: free-roaming all year round (67.8\%) and restricted herding (32.2\%) during the cropping season. The major constraints for goat production were infectious and parasitic diseases $(0.45)$, inadequate veterinary services (0.39), predators (0.091), marketing problem (0.03) and poor man-
\end{abstract}


agement (0.01). Arab, Felata, and Gumuz goats give first birth at the age of $13.65 \pm 0.40,12.90 \pm 0.29$ and $12.54 \pm 0.43$ months, kidded at every $8.52 \pm$ $0.41,7.85 \pm 0.25$ and $7.67 \pm 0.22$ months and produce $0.52 \pm 0.03,0.61 \pm 0.02$, and $0.51 \pm 0.01$ liter of milk, respectively. Uncontrolled natural mating is the dominant breeding system, and bucks and does run together throughout the year. Size, growth rate, body conformation and age were the preferred traits in selecting bucks, whereas does were selected based on size, multiple birth, milk yield and kidding interval. Therefore, in order to utilize the current growing demand for goat meat at local and international markets, improving the production environment, particularly health and nutrition, genetic and production technologies is necessary.

\section{Keywords}

Constraints, Feed Resources, Goats, Husbandry Practice

\section{Introduction}

Goats play a vital role in the livelihoods of small-scale farmers in developing countries. They contribute to food security and reduce seasonal food variability and availability, directly through milk and meat production and indirectly through cash earned from the sale of their products. In semi-arid areas, goats have comparative advantages compared to cattle, since they are more tolerant to droughts, utilize a wider diversity of plants, and have a higher reproductive rate which enables them to recover quickly. In Ethiopia, goats are reared entirely in mixed crop livestock, and pastoral and agro pastoral systems and in wide range of agro-climates covering hot arid and semiarid areas to the cold humid highlands [1]. The goat population of the country is estimated at 32.7 million [2] and it grows at the rate of $1.1 \%$ with off-take rate of $34.37 \%$ [2]. They contribute about $16.8 \%$ and $16.7 \%$ of the total meat and milk supply consumed in the country [3] [4].

The demand for goat meat consumption is currently rising due to the rapid population growth, urbanization, and the growing export market [5]. However, despite the large size of goats that are reared by smallholder, the productivity per unit of animal is low, hence its contribution to the country's economy is far below the potential. This is attributed to poor nutrition, prevalence of diseases, and lack of appropriate breed and breeding strategies. So far, various research activities on characterizations of production system and constraints hindering productivity were conducted. However, little consideration was given to the participation of farmers in research and development activities, as a result of which adoption of technologies that enhance productivity is insignificant. Therefore, innovative research and development programs are required to increase the productivity of the flock and subsequently improve the contribution of goats to the livelihood of smallholder producers and the economy of the country; to their tolerance to the adverse and hot climate conditions of the area. 
In order to develop technologies that can sufficiently address the problems faced by smallholder producers, a baseline survey is required indoor to understand production characteristics, diversity of management strategies, breeding practices involved, major constraints and opportunities. Such an approach will help to establish viable on-station and on-farm research, which result can be utilized by target smallholder producers. Therefore, the present study was conducted to assess the existing traditional goat production systems, management and breeding practices and to identify and prioritize production constraints and opportunities.

\section{Materials and Methods}

\subsection{Study Areas}

The study was conducted in the year 2017 in Benishangul-Gumuz Regional State of Ethiopia. The region is located in the north western part of the country between geographical coordinates of $9^{\circ} 17^{\prime}$ to $12^{\circ} 6^{\prime} \mathrm{N}$ latitude and $34^{\circ} 10^{\prime}$ to $37^{\circ} \mathrm{E}$ longitudes with altitude ranging 580 to 2731 masl [6]. The area has mean annual rainfall ranging from $700-1800 \mathrm{~mm}$ with a minimum and maximum average temperature of $22^{\circ} \mathrm{C}$ and $43^{\circ} \mathrm{C}$, respectively [7]. The study was carried out in Agalo-Meti, Bambasi and Mandur districts of the Kamashi, Assosa, and Metekel Zones, respectively. Goats are the most important livestock species raised by the farming communities in the region and it possess about 602,840 thousand heads of goat, which is about $1.84 \%$ of the national goat population [2]. Earlier phenotypic characterization identified Felata, Arab, Gumuz, Oromo and Agew goat types of which the first three are recognized as the most tolerant to the harsh environmental and climatic conditions of the region [8].

\subsection{Sampling Technique and Sample Size}

A multi-stage sampling procedure was adopted for the selection of respondents among smallholder farmers in the selected districts. In the first stage, the three districts were purposely selected based on the population of the goat types of interest in the present study (Felata, Arab and Gumuz) and accessibility to market and infrastructure. These goat types are considered because of their geographical coverage, relatively large population and adapted to local environment. In the second stage, five rural kebeles (lowest political administrative units) from each district were selected based on similar criteria. From the kebeles ten to 15 households having an average flock size of $\geq 4$ goats and a minimum of one year experience in goat production were selected using systematic random sampling technique. A total of 59, 60 and 58 households were taken from Agalo-Meti, Bambasi and Mandura districts, respectively, which was determined according to the proportionate sampling technique provided by [9]. Each of the 177 households was interviewed individually using semi-structured questionnaires.

$$
n=\frac{N}{1+N(e)^{2}}
$$




\subsection{Data Type}

Both primary and secondary data in relation to goat production characteristics, management and breeding, existing constraints and opportunities were collected. Primary data were obtained by interviewing the selected smallholder farmers in each of the kebeles. Major questions included in the questionnaires were socio-economic characteristics, purposes of keeping goats, traits of importance, flock size and structure, production and management systems (housing, feed, water, health and breeding), reproductive characteristics, production constraints and opportunities. The focus group discussions (FGD) was held in nine selected kebeles (three kebeles per district) that constitutes 84 men and women ( $9-10$ members per discussion) including farmers from different age, wealth groups, education status and gender issues, key informant interviews (KII), which include 21 key informants at district level experts of livestock development agency, livestock extension agents, animal health assistant and agricultural researchers and field visit was conducted at each of the Kebele. Secondary data that include agro-ecology of the study areas, livestock population, production and extension delivery system were also collected from published and unpublished documents referring to published literature and gray documents from various offices in the selected districts and respective Zone and Regional offices.

\subsection{Data Analysis}

The data collected by using semi-structured questionnaire were coded and entered in to Microsoft Excels and imported to Statistical Package for Social Sciences (SPSS, version 20 software). Descriptive statistics were used to express quantitative variables. Mean and Standard error \pm (SE) were used to describe quantitative data while percentage was used for describing qualitative characteristics. Farmer's preference rankings were summarized into index as weighted averages. The indices were calculated as suggested by [10].

$$
\text { Index }=\frac{\operatorname{sum}(3 \times \mathrm{NHRF}+2 \times \mathrm{NHRS}+1 \times \mathrm{NHRT}) \text { given for an individual reasons }}{\operatorname{sum}(3 \times \mathrm{NHRF}+2 \times \mathrm{NHRS}+1 \times \mathrm{NHRT}) \text { given for all reasons }}
$$

where: NHRF = number of households ranked first;

NHRS = number of households ranked second;

$\mathrm{NHRT}=$ number of household ranked third.

\section{Results and Discussion}

\subsection{Socioeconomic Characteristics of Household}

\subsubsection{Demographic Characteristics}

The majority of the households were male-headed and only (19.2\%) were female-headed (Table 1). Most of the respondents have age below sixty five years with good experience in goat rearing. The average family size for the districts were comparable to the national average (5.2) [11], but lower than the average family size of 7 (range 3 - 12) reported from Bati, Meta and Kebri-Beyah districts 
Table 1. Demographic characteristics of the sampled household heads.

\begin{tabular}{|c|c|c|c|c|}
\hline \multirow[b]{2}{*}{ Parameters } & \multicolumn{3}{|c|}{ Districts } & \multirow{2}{*}{$\begin{array}{c}\text { Overall } \\
(\mathrm{N}=177)\end{array}$} \\
\hline & $\begin{array}{l}\text { Agalo-Meti } \\
\quad(\mathrm{N}=59)\end{array}$ & $\begin{array}{l}\text { Bambasi } \\
(\mathrm{N}=60)\end{array}$ & $\begin{array}{l}\text { Mandura } \\
(\mathrm{N}=58)\end{array}$ & \\
\hline \multicolumn{5}{|l|}{ Household heads (\%) } \\
\hline Male & $46(78.0)$ & $48(80.0)$ & $49(84.5)$ & $143(80.8)$ \\
\hline Female & $13(22.0)$ & $12(20.0)$ & $9(15.5)$ & $34(19.2)$ \\
\hline \multicolumn{5}{|l|}{ Age group (\%) } \\
\hline$\leq 40$ years & $48(81.3)$ & $35(58.3)$ & $41(70.7)$ & $124(70.1)$ \\
\hline$\geq 40-50$ years & $6(10.2)$ & $13(21.7)$ & $12(20.7)$ & $31(17.5)$ \\
\hline$\geq 50-60$ years & $2(3.4)$ & $8(13.3)$ & $3(5.2)$ & $13(7.3)$ \\
\hline$>60$ years & $3(5.1)$ & $4(6.7)$ & $2(3.4)$ & $9(5.1)$ \\
\hline \multicolumn{5}{|l|}{ Education level (\%) } \\
\hline Illiterate & $14(23.7)$ & $17(28.3)$ & $20(34.5)$ & $51(28.8)$ \\
\hline Read and write & $24(40.7)$ & $23(38.3)$ & $21(36.2)$ & $68(38.4)$ \\
\hline Primary education $\left(1^{\text {st }}-8^{\text {th }}\right.$ Grade $)$ & $11(18.6)$ & $12(20.0)$ & $9(15.5)$ & $32(18.1)$ \\
\hline Secondary education $\left(9^{\text {th }}-12^{\text {th }}\right.$ Grade $)$ & $10(17.0)$ & $8(13.3)$ & $8(13.3)$ & $26(14.7)$ \\
\hline \multicolumn{5}{|l|}{ Household characteristics (Mean \pm SD) } \\
\hline Family size & $5.1 \pm 2.42$ & $5.7 \pm 2.81$ & $4.7 \pm 2.29$ & $5.2 \pm 2.54$ \\
\hline Land holding (ha) & $4.3 \pm 2.97$ & $4.6 \pm 2.32$ & $5.7 \pm 2.94$ & $4.9 \pm 2.81$ \\
\hline
\end{tabular}

$\mathrm{N}$ = number of household; $\mathrm{SD}=$ standard deviation; Numbers in parenthesis are percentages.

goat keepers [12]. Relatively higher family size per household was observed in Bambasi may be because of the polygamous marriage practiced in the district. The high proportion of literate have a vital role in adopting and promoting new technologies and keeping records and information related to goat production when needed. The literacy rate was comparable to that reported for Goma district (70\%) goat keepers [13] and greater than for small ruminant keepers reported by other authors [14] [15]. The overall mean landholding was higher than the national average $(1.6 \mathrm{ha} / \mathrm{hh})$ reported by [16] which could be ascribed to low population density in the study area.

\subsubsection{Farming Activities}

The farming system of the area is mixed crop-livestock (Table 2) and there are no households engaged in only crop cultivation or livestock rearing. The main crops cultivated are sorghum, finger millet, mango, sesame, maize, soybean, groundnut and peppers. Most of the farmers engage in non-farm activities to generate additional income besides crop and livestock production. 
Table 2. Major farming and non-farming activities in the study districts.

\begin{tabular}{ccccc}
\hline Activities & \multicolumn{3}{c}{ District } & Overall \\
\cline { 2 - 4 } & $\begin{array}{c}\text { Agalo-Meti } \\
(\mathrm{N}=59)\end{array}$ & $\begin{array}{c}\text { Bambasi } \\
(\mathrm{N}=60)\end{array}$ & $\begin{array}{c}\text { Mandura } \\
(\mathrm{N}=58)\end{array}$ & ( = 177) \\
\hline $\begin{array}{c}\text { Major farming activity (\%) } \\
\text { Mixed livestock-crop production }\end{array}$ & $59(33.30)$ & $60(33.90)$ & $58(32.8)$ & $177(100.00)$ \\
Non farming activity (\%) & & & & \\
"Forest products & $31(52.50)$ & $27(45.00)$ & $34(58.60)$ & $92(51.90)$ \\
Traditional gold mining & $8(13.60)$ & $21(35.00)$ & 0.00 & $29(16.40)$ \\
Handicraft & $15(25.40)$ & $9(15.00)$ & $14(24.10)$ & $38(21.50)$ \\
Labor work & $5(8.50)$ & $3(5.00)$ & $10(17.20)$ & $18(10.20)$ \\
\hline
\end{tabular}

$\mathrm{N}$ = number of household; "encompasses fire wood, charcoal making and construction materials sailing; Numbers in parenthesis are percentages.

\subsubsection{Livestock Holding}

The livestock species kept includes cattle, sheep, goats, equines and chicken (Table 3). The number of goats owned was significantly higher followed by cattle, which could be due to their tolerance to the adverse and hot climate conditions of the area. The availability of vast communal and extensive grazing and browsing land may also contribute to herding of greater number of goats and cattle. Even though purposive sampling of the respondent may not fully reflect the true picture of the existing livestock ownership pattern in the study area, the current finding agrees with [17] that reported goats and cattle to dominant livestock species in the study area.

None of the respondents owned mules and horses. Donkeys are mainly kept for transport of goods and farm produce. Ownership of mules and horses is very rare. Only very few number of farmers own a mule or a horse. Lower number of sheep than goat might be due to goats are relatively tolerant of high temperature, better able to survive in the lowland and in drought years, more importance as suppliers of milk to the household, so farmers prefer goats compared to those sheep [18].

The group discussants revealed that farmers usually consider sheep as a highland animal. They also said that the high number of goat is associated with their capacity to live in very harsh and high load of disease environment. Moreover, they believe that goats serve more as immediate source of income, have short generation interval, high prolificacy and fast growth rate compared to other species. These findings are consistent with the earlier report of [19] who reported similar reasons for keeping greater number of goats in Metema district. This result show that goat improvement program and extension strategies could be easily and successfully employed in the study areas than sheep.

\subsubsection{Goat Breeds and Flock Structure}

The dominantly reared indigenous genotypes in the study districts are composed of three major local breeds, namely Arab, Felata and Gumuz (Table 4). The name referred to the ethnic group who dominantly raised them and the places 
Table 3. Mean number of livestock holdings per household in the study area (Mean \pm $\mathrm{SD})$.

\begin{tabular}{ccccc}
\hline \multirow{2}{*}{ Livestock species } & \multicolumn{4}{c}{ District } \\
\cline { 2 - 5 } & Agalo-Meti & Bambasi & Mandura & Overall \\
\hline Cattle & $2.46 \pm 0.23$ & $3.87 \pm 0.57$ & $3.59 \pm 0.93$ & $3.31 \pm 0.58$ \\
Sheep & $2.02 \pm 0.98$ & $2.67 \pm 0.63$ & $2.49 \pm 0.65$ & $2.39 \pm 0.75$ \\
Goat & $9.81 \pm 1.08$ & $8.31 \pm 1.16$ & $8.71 \pm 0.88$ & $8.97 \pm 1.04$ \\
Chicken & $3.63 \pm 0.86$ & $5.63 \pm 1.22$ & $5.50 \pm 1.15$ & $4.92 \pm 1.08$ \\
Donkey & $0.61 \pm 0.68$ & $1.02 \pm 0.52$ & $0.90 \pm 0.69$ & $0.84 \pm 0.63$ \\
\hline
\end{tabular}

$\mathrm{SD}=$ standard deviation

Table 4. Breeds kept by the respondent households in the study area.

\begin{tabular}{ccccc}
\hline Goat breed & \multicolumn{3}{c}{ Districts } & $\begin{array}{c}\text { Overall } \\
(\mathrm{N}=177)\end{array}$ \\
\cline { 2 - 4 } & $\begin{array}{c}\text { Agalo-Meti } \\
(\mathrm{N}=59)\end{array}$ & $\begin{array}{c}\text { Bambasi } \\
(\mathrm{N}=60)\end{array}$ & $\begin{array}{c}\text { Mandura } \\
(\mathrm{N}=58)\end{array}$ & $98(55.37)$ \\
Gumuz & $56(94.92)$ & $0(0.00)$ & $42(72.41)$ & $28(15.82)$ \\
Felata & $3(5.08)$ & $14(23.33)$ & $11(18.96)$ & $42(23.73)$ \\
Arab & $0(0.00)$ & $42(70.00)$ & $0(0)$ & - \\
Guxed crosses & & & & - \\
Arab $\times$ Oromo & $0(0.00)$ & $4(6.67)$ & $0(0.00)$ & - \\
\hline
\end{tabular}

$\mathrm{N}=$ number of household; Numbers in parenthesis are percentages.

from where the goat breeds were originated. [8] Identified five goat types, namely Felata, Arab, Gumuz, Oromo and Agew. Felata, Arab and Gumuz goats dominate the arid and semi-arid zones of the region. Mixed crosses of Gumuz with Agew and Felata with Oromo goat types were also reported in some districts where Agew and Oromo people are bordering the study area.

The flock size was relatively higher in Agalo Meti, followed by Mandura district, which could be attributed to high rate of multiple birth and short kidding interval of Gumuz compared to the other breeds (Table 5). The mean flock size of goats in the present study was lower than reported in previous works [20] [21].

The proportion of does in the current study was comparable to $39.4 \%$ reported in previous studies [19]. However, it is slightly higher than $37.5 \%$ reported for goat flock in different parts and farming system in Ethiopia [12]. This finding is also in agreement with the scenario in other African countries [22] [23]. The higher proportion of females may be attributed to the prevalent practice of retaining females for breeding while males are either castrated in order to fetch higher price or sold at early age to meet the cash demand of the household. 
Table 5. Goat flock structure in the study area.

\begin{tabular}{ccccc}
\hline & \multicolumn{3}{c}{ District } & $\begin{array}{c}\text { Overall } \\
\text { Category }\end{array}$ \\
\cline { 2 - 4 } & Agalo Meti & Bambasi & Mandura & $(\mathrm{N}=177)$ \\
\cline { 2 - 4 } & Mean $\pm \mathrm{SD}$ & Mean $\pm \mathrm{SD}$ & Mean $\pm \mathrm{SD}$ & Mean $\pm \mathrm{SD}$ \\
\hline Goat & $9.81 \pm 1.08$ & $8.31 \pm 1.16$ & $8.71 \pm 0.88$ & $8.97 \pm 1.04$ \\
Male kids $<6$ months & $1.25 \pm 0.63$ & $0.84 \pm 1.09$ & $0.85 \pm 1.01$ & $0.98 \pm 0.94$ \\
Female kids $<$ 6 months & $1.51 \pm 0.92$ & $1.12 \pm 1.06$ & $1.05 \pm 1.14$ & $1.23 \pm 1.06$ \\
Male goat 6 to 12 months & $1.02 \pm 0.63$ & $0.83 \pm 1.03$ & $0.98 \pm 1.07$ & $0.94 \pm 0.93$ \\
Female goat 6 to 12 months & $1.22 \pm 0.67$ & $1.00 \pm 1.04$ & $1.17 \pm 1.12$ & $1.13 \pm 0.97$ \\
Male goat $>1$ year & $0.69 \pm 0.65$ & $0.47 \pm 0.78$ & $0.95 \pm 0.72$ & $0.71 \pm 0.74$ \\
Female goat $>1$ year & $3.71 \pm 0.46$ & $3.81 \pm 0.40$ & $3.17 \pm 0.91$ & $3.56 \pm 0.69$ \\
Castrated males & $0.41 \pm 0.81$ & $0.24 \pm 0.51$ & $0.60 \pm 0.96$ & $0.42 \pm 0.79$ \\
\hline
\end{tabular}

$\mathrm{N}$ = number of respondent; $\mathrm{SD}=$ standard deviation.

\subsubsection{Reasons for Keeping Goats}

The first objective for keeping goats was income generation through sale of live animals (Table 6), which is in agreement with earlier studies [24] [25] [26]. The second main reason for goat rearing was means of saving or insurance against any unexpected disaster such as crop failure followed by source of meat. [12] showed that meat and milk are the second and third important reasons for keeping goats in Bati, Meta and Kebri-Beyah districts indicating the shift in the order of functions of goats based on production system and the community keeping them.

The current finding implies that sale of goats to generate cash constitute the primary purpose among the other benefits of keeping goats in all the study districts. Only few farmers kept goats for manure production, breeding, cultural and rituals. Households in different study districts reported that goats are often slaughtered in honor of a special guest, a visiting friend or relative, festivities and religious rituals.

The focus group discussants (FGDs) stated that the cash income from sale of goats was spent on purchase of farm inputs, school fees, pay taxes, human and livestock medical expenses and re-stocking. The trend of expenditure at all the study districts was similar. None of the surveyed farmers in the study districts kept goats for milk and skin production.

\subsection{Goat Production and Management}

\subsubsection{Feed Resources and Feeding Practices}

Free grazing and browsing are the common feeding systems of goats in all the study districts. The availability of feed resources varied depending on the seasons with respect to quality, quantity and type of feed (Table 7). The major feed resource for goats in all the study districts are natural pasture which comprise of a wide variety of naturally occurring perennial and annual grasses, legumes, herbaceous and browse species both during dry and wet seasons, as also reported 
Table 6. Reasons for keeping goats as ranked by respondents in the study areas.

\begin{tabular}{ccccc}
\hline \multirow{2}{*}{ Purpose } & \multicolumn{3}{c}{ Rank } & \multirow{2}{*}{ Index } \\
\cline { 2 - 4 } & Rank 1 & Rank 2 & Rank 3 & \\
\hline Cash income & 140 & 20 & 14 & 0.44 \\
Saving/insurance & 24 & 145 & 8 & 0.34 \\
Meat for home consumption & 13 & 12 & 139 & 0.18 \\
Manure & 0 & 0 & 11 & 0.01 \\
Breeding & 0 & 0 & 19 & 0.02 \\
Cultural rituals & 0 & 0 & 7 & 0.006 \\
\#Others & 0 & 0 & 4 & 0.004 \\
\hline
\end{tabular}

"encompasses prestige, dowry and ceremonies; Index $=\Sigma[3$ for rank $1+2$ for rank $2+1$ for rank 3$]$ for particular purpose divided by $\Sigma[3$ for rank $1+2$ for rank $2+1$ for rank 3$]$ for all purposes.

Table 7. Ranking of major feed resources in the study districts in wet and dry season.

\begin{tabular}{ccccc}
\hline \multirow{2}{*}{ Available feed sources } & \multicolumn{3}{c}{ Rank } & Index \\
\cline { 2 - 3 } During wet season & Rank & Rank 2 & Rank 3 & \\
Natural pasture & 128 & 7 & 3 & 0.49 \\
Browse species & 49 & 64 & 24 & 0.36 \\
Non-conventional feeds & 0 & 32 & 8 & 0.09 \\
Grains and grain by-product & 0 & 17 & 16 & 0.06 \\
During dry season & & & & 0.54 \\
Browse species & 91 & 94 & 10 & 0.22 \\
Natural pasture & 59 & 9 & 3 & 0.12 \\
Crop aftermath & 16 & 25 & 12 & 0.08 \\
Grains and grain hulls & 11 & 13 & 9 & 0.04 \\
\hline Non-conventional feeds & 0 & 6 & 18 & \\
\hline
\end{tabular}

Index $=\Sigma[3$ for rank one $1+2$ for rank $2+1$ for rank 3$]$ for an individual feed resource divided by $\Sigma[3$ for rank $1+2$ for rank $2+1$ for rank 3] for all feed resources.

in other studies [27]. The wider utilization reported for indigenous browses in the study districts were attributed to their abundant availability, being remains green and high nutrient content during the dry seasons. Grazing and browsing occurs on communal grazing lands, bush and shrub areas, roadsides, riversides, fallow lands and on crop land following harvest.

Although there is difference in utilization across months of the years, communal grazing lands and bush and shrub areas are utilized throughout the year. Consistent with the current study, [13] reported similar feed resources and grazing and browsing areas. Private grazing land was not common in the area. This might be due to the greater access to communal grazing land. 
The majority of the respondents (98.3\%) have no experience of cultivating and utilizing improved fodder which was ascribed to poor extension delivery systems and lack of improved seeds. Reports from other place [28] showed that smallholder farmers practice improved fodder production and utilization. Moreover, feed conservation practices and crop residue utilization in the present study area are very poor and non-existing among most farmers.

The focus group discussion revealed that the availability of goats' feed in the area was not a constraint for productivity of goats. This is due to the availability of vast communal grazing land, abundant browse shrubs, bushes and tree leaves, and low stocking density, with only a slight feed shortage during the peak dry seasons (March to the end of April).

During these months, most of the grazing areas become bare and availability of browse, bushes and shrubs is declining. This is mainly due to the use of uncontrolled burning of the rangeland and shedding of browse species leaves. Some farmers $(56.5 \%)$ reported that they rarely practice supplementing goats with non-conventional feeds and whole grain and grain hulls (maize, sorghum and soybean), by-product from local brew (Atella and Brint), milling by-products and household food leftovers. Supplementation of common salt alone and home mix (blending milling residue with salty water) is widely practiced in all the study districts. Similarly, [29] reported that smallholder producers in Goma district provide non-conventional feed resources such as chat left over, home left-over, fruit left over, Enset (Ensete ventricosum) and banana parts, weeds and crop tillers and fillers as a supplement feed for small ruminants.

The majority of respondents usually provide supplements to lactating does, adult breeding bucks and finishing goats to enhance milk production for the growth of kids, maintain their body condition for mating and to have more muscular growth and fetch high market price, respectively. This is in line with the report of [30] in Degehabur Zone, Eastern Ethiopia. Forty four percent of the respondents across all the study districts do not practice supplementation due to lack of knowledge on the use of supplement (42.3\%), some believe that supplementation is not required (34.6\%) and supplements are not easily available (23.1\%).

\subsubsection{Water Sources}

Consistent watering improves feed intake and reduces time and energy invested in walking to and waiting at watering points. Watering is therefore an important management component, which is often not addressed. Perennial rivers, ponds and hand dug wells were the major sources of water during dry and wet seasons followed by borehole, streams and springs (Table 8). These were in agreement with the report of [31] who noted rivers to be an important source of water during dry and wet seasons in crop livestock production system.

The importance of water sources was similar from one district to another during both seasons. Watering goats by fetching water from community water pumps and carrying it home for kids, sick and born goats was common. 
Table 8. Source of water during dry and wet seasons in the study districts.

\begin{tabular}{cccc}
\hline \multirow{2}{*}{ Source } & \multicolumn{2}{c}{ Season } & $\begin{array}{c}\text { Overall } \\
\text { nynn}\end{array}$ \\
\cline { 2 - 3 } & Dry season $(\mathrm{N}=177)$ & Rainy season $(\mathrm{N}=177)$ & $76(42.94)$ \\
Rivers & $121(68.36)$ & $32(18.08)$ & $52(29.38)$ \\
Ponds & $18(10.17)$ & $87(49.15)$ & $20(11.30)$ \\
Hand dug wells & $24(13.56)$ & $16(9.04)$ & $12(6.78)$ \\
Streams & 0.00 & $25(14.12)$ & $13(7.34)$ \\
Borehole & $14(7.91)$ & $12(6.78)$ & $3(1.69)$ \\
Spring & 0.00 & $5(2.82)$ & \\
\hline
\end{tabular}

$\mathrm{N}=$ number of household; Numbers in parenthesis are percentages.

Watering points were evenly distributed across the grazing and browsing areas and there was no marked problem with respect to access to water by goats and other livestock species in all the study districts. The watering frequency of goats in dry and wet season is free access as they required. This might be related to the accessibility of watering points in close distances to grazing lands.

\subsubsection{Housing Management}

Appropriate housing reduces mortality and allows effective animal health management. The houses for goats in the study districts are well constructed to provide a good physical environment for the goats. According to the survey result and personal observations, about $89.3 \%$ of the respondents housed their goats in a well-shaded separately constructed house adjacent to the family house at night and during the day when the heat intensity is high. Only sick goats and suckling kids were retained alone and used the same house with family until recovering and weaning. None of the respondents had provision for accommodating different age groups. About $31.1 \%, 46.6 \%$ and $22.3 \%$ shelter their goats for reasons of protecting from adverse climatic stress (extreme heat and rain), protection against predators and preventing theft, respectively. Unlike the current study [31] found that majority (83.82\%) of goat producers in Ziquala districts confine goats without roof and small proportion (18.18\%) of farmer confine their goats in family house.

Goats house in the study areas have a raised floor made of slatted wooden. This floor or platform is raised about $1.5-2.0 \mathrm{~m}$ from the ground. The slats allow dung to fall down to the floor. The fallen fecal materials from the pens are used as manure. The houses are made from materials available in the area such as bamboo trees, any wood bars and grass thatches. Recently migrants and large-scale agricultural investors (10.7\%) who had big flocks build different types of housing for the dry and wet season. During the dry season corrals are open-top, fences built from tree branches to confine animals during the night and protect them from predators and roofed barns for the rest rainy seasons was the second goat housing type in the study districts.

\subsubsection{Herding Practices}

Two types of goat herding practices were distinguished on the basis of animal confinement (Table 9). These are free-roaming/grazing all year round (67.8\%) and restricted/confined herding (32.2\%) during the cropping season (June to November). 
Table 9. Herding practices across the study districts.

\begin{tabular}{ccccc}
\hline \multicolumn{5}{c}{ District } \\
\hline Particulars & $\begin{array}{c}\text { Agalo Meti } \\
(\mathrm{N}=59)\end{array}$ & $\begin{array}{c}\text { Bambasi } \\
(\mathrm{N}=60)\end{array}$ & $\begin{array}{c}\text { Mandura } \\
(\mathrm{N}=58)\end{array}$ & $\begin{array}{c}\text { Overall } \\
(\mathrm{N}=177)\end{array}$ \\
\hline $\begin{array}{c}\text { Herding practice (\%) } \\
\text { Free-roaming }\end{array}$ & $51(86.40)$ & $32(53.30)$ & $37(63.80)$ & $120(67.80)$ \\
Confined/during farming & & & & \\
season only & $8(13.50)$ & $28(46.70)$ & $21(36.20)$ & $57(32.20)$ \\
\hline
\end{tabular}

$\mathrm{N}=$ number of household; Numbers in parenthesis are percentages.

In free-roaming system, the goats are released in the morning to forage freely without any restrictions. In almost all study sites, where the communities practiced hoe cultivation around the homestead, the type of management experienced was free roaming all year round. In this system, goats are more prone to predators since they travel an attended over long distance in search of feed.

In Mandura and Bambasi districts herding was practiced during the cropping season (June to November) to prevent goats from straying into cropping fields. Consistent with the current study [32] reported that small ruminants are herded during wet season to protect crop lands. All age and sex classes of goat are herded together at grazing field. Most farmers $66.1 \%, 61.7 \%$ and $68.3 \%$ in Agalo Meti, Bambasi and Mandura herded goats separately from neighboring goats. Goats on the average stay about 6 to 7 hours in grazing/browsing during the day time.

\subsubsection{Major Diseases and Veterinary Services}

Diseases and parasites are one of the major constraints that contribute to the low productive and reproductive performance of goats, which in turn cause high mortality rates of animals. Farmers of the study areas identify and recognize the type of diseases and parasites affecting their animals by recognizing their major symptoms and local names through experience. Table 10 summarizes the most frequently occurring goat diseases as reported by the respondents and their corresponding index value. In all the study districts, the major goat diseases identified were Peste des Petits Ruminants (PPR), Trypanosomes, Contagious Caprine Pleuro Pneumonia (CCPP) and foot rot followed by pasteurellosis, Orf (Sore mouth) and external parasite. To a lesser extent, goats suffered from goat pox and internal parasite. The present findings were in line with the finding of earlier works [19] that identified the same diseases.

Although the goats were not routinely dewormed on a regular basis, parasitic gastro-enteritis was negligible and clinically unimportant. This was due mainly the goats being kept on slatted floors which can easily allow dung to fall down to the floor which reduces recontamination of goats by the parasites. 
Table 10. Major goat diseases and parasites as ranked by respondents in the study district.

\begin{tabular}{|c|c|c|c|c|c|}
\hline \multirow{2}{*}{ Diseases and parasites } & \multicolumn{4}{|c|}{ Rank } & \multirow{2}{*}{ Index } \\
\hline & Rank 1 & Rank 2 & Rank 3 & Rank 4 & \\
\hline Peste des petits Ruminants (PPR) & 140 & 24 & 6 & 3 & 0.45 \\
\hline Foot root & 0 & 3 & 10 & 6 & 0.02 \\
\hline Pasteurellosis, & 4 & 13 & 9 & 6 & 0.06 \\
\hline Contagious Caprine Pluero Pneumonia & 21 & 53 & 10 & 3 & 0.19 \\
\hline Trypanosomes & 5 & 18 & 56 & 22 & 0.14 \\
\hline Internal parasite & 0 & 4 & 6 & 0 & 0.02 \\
\hline Goat pox & 0 & 9 & 5 & 9 & 0.03 \\
\hline External parasite & 6 & 22 & 7 & 2 & 0.07 \\
\hline${ }^{\#}$ Others & 0 & 4 & 7 & 3 & 0.02 \\
\hline
\end{tabular}

"encompasses abortion, foot and mouth disease and enteritis: Index $=\Sigma[4$ for rank $1+3$ for rank $2+2$ for rank $3+1$ for rank 4$]$ for an individual disease divided by $\Sigma[4$ for rank $1+3$ for rank $2+2$ for rank $3+1$ for rank 4] for all diseases.

The key informants revealed that among the major diseases Peste des Petits Ruminants (PPR) was an acute viral disease causing high economic losses due to high rate of mortality and morbidity, especially among kids. The focus group discussants revealed that abortion in the does is high during the peak dry seasons (May to end of April). The reasons might be due to prolonged heat stress caused by high ambient temperature (between $32^{\circ} \mathrm{C}$ to $40^{\circ} \mathrm{C}$ ) during these months. The health service delivery system is mainly $(93.8 \%)$ provided by government health posts located in the village as one of the package of the villagization program [33] [34] reported similar avenue of health delivery system.

Yet, there is still a problem of poor health management of the goat flock under smallholder framers. The focus group discussants revealed that the problems related to goat's health management were unreliable supply of drugs, vaccines and equipment, high cost of drugs, unavailability and turnover of practitioners and skill of assistant veterinarian. The above results were confirmed during the key informant discussion with Zone and district veterinarians.

Due to the inadequacy of the government health service $27.7 \%$ of the households revealed that they uses medicinal plants and releasing blood/branding practices to cure sick animals. However, they sometimes causes serious problem due to higher dose and lack of knowledge about the disease type. A little more than three quarters of the farmers (76.3\%) reported high prevalence of diseases during the peak dry season (April to end of May) which could be related to adverse climatic stress.

\subsection{Reproductive Performance}

\subsubsection{Age at First Service}

According to the respondents, the age at puberty was defined as the age at which female produced fertile eggs and gets pregnant. The average age at puberty reported by the farmers was relatively shorter for Felata and Gumuz than Arab goats (Table 11) similar with that reported by [19]. 
Table 11. Reproductive performance and milk production of indigenous goats in the study districts.

\begin{tabular}{cccc}
\hline \multirow{2}{*}{ Parameters } & \multicolumn{3}{c}{ Breed } \\
\cline { 2 - 4 } & Arab & Felata & Gumuz \\
\cline { 2 - 4 } & Mean \pm SD & Mean \pm SD & Mean \pm SD \\
\hline Age at first mating (months) & $8.54 \pm 0.40$ & $7.75 \pm 0.41$ & $7.48 \pm 0.35$ \\
Age at first kidding (months) & $13.65 \pm 0.40$ & $12.90 \pm 0.29$ & $12.54 \pm 0.43$ \\
Kidding interval (months) & $8.52 \pm 0.41$ & $7.85 \pm 0.25$ & $7.67 \pm 0.22$ \\
Litter size & $1.58 \pm 0.18$ & $1.73 \pm 0.14$ & $1.91 \pm 0.07$ \\
Milk yield/head/day (liter) & $0.52 \pm 0.03$ & $0.61 \pm 0.02$ & $0.59 \pm 0.01$ \\
\hline
\end{tabular}

$\mathrm{SD}=$ standard deviation

\subsubsection{Age at First Kidding}

Age at first kidding is a good indicator of sexual maturity in does. The overall mean age at first kidding (13.03 \pm 0.37 months) obtained in this study is lower than 16.8 months reported for other indigenous goats of Ethiopia [12] [35].

\subsubsection{Kidding Interval}

The average kidding interval for the three indigenous goat types recorded implies the possibility of achieving three kidding over a two year period. However, there was a variation in the kidding interval reported by the farmers despite the fact that the breeding males always run with the breeding females throughout the year. This kidding interval indicated the ability of the goats to breed throughout the year and these shorter kidding intervals are more common in traditional systems where uncontrolled mating is practiced.

The finding in the current study was comparable with [36] who reported 8.07 months for Arsi-Bale goat types under farmers' management condition. Other on-farm research works in Ethiopia also reported more or less similar kidding intervals ranging between 7.5 and 8.4 months [18] [37] [38]. However, it is lower than kidding interval recorded for Abergelle $(11.31 \pm 2.2)$ and central highland (10.3 \pm 1.42 months) goats [19] [39].

\subsubsection{Liter Size}

About $45.2 \%$ of the kidding was twins and (4.2\%) triplets and reported to vary among parities. The focus group discussion confirmed that the pattern of litter size increased as the age of does advanced. At first kidding, the litter size in most cases is single and increases to twins to the middle age and remains constant after fifth and sixth parity. In rare cases, Gumuz and Felata goats produce triplets and quadruplets at their peak reproductive age. The Gumuz goat reached age at puberty earlier, gave first births sooner, have short kidding interval and high litter size. The observed variation may be associated with inherent genetic and various management practices. An average litter size of about 1.74 [13] and 2.07 [40] were reported in other indigenous goat breeds. 


\subsection{Milk Production and Consumption}

The result showed that Felata goats produce 0.61 liter of milk daily without supplementation (Table 11). This is a good indication of high productive efficiency.

The overall mean milk yield of goats in the present study was higher than the previous work [41] who reported $0.4 \pm 0.2$ liter/head/day in different goats reared in various agro-ecologies. Most of the respondents (88.1\%) do not utilize goat milk. The major reasons mentioned were for good growth of kids (55.1\%), low lactation yield of goats $(20.5 \%)$, culture taboo $(8.3 \%)$ and lack of awareness of the importance $(16.0 \%)$ of goat milk. This result was not in agreement with the earlier reports of [12] who reported $80 \%$ of the households use goat milk for consumption. On the other hand, in some parts of Bambasi and Mandura districts, where the Felata goat breed are found, the households milk goats for consumption by infants, the elderly and sick family members.

\subsection{Skin Production and Utilization}

Goat skins are important by-products. The majority (58.2\%) of the producers' sale goat skins, whereas the rest $(41.8 \%)$ do not sale in the formal market chain (Table 12). The focus group discussants revealed that producers are discouraged by limited access to market, lower market price of goat skins and high transportation cost to local traders/collection centers to sale skins at formal market with relatively better price. This was also observed in similar studies that indicated goat skins are rarely marketed [19] [42]. Therefore, producers are either discards it in case of putrefaction or keep products to produce utensils for household use or sale to local traditional skin processors for domestic market. There is a high fluctuation of price in different seasons and also in different destinations for sale but most households did not get this opportunity due to lack of information.

The most frequently identified causes for skin defects were putrefaction/staling, flay cut/hole and flesh remnants (Table 12). Contamination with dirt, damages by

Table 12. Major causes of goat skin defects as ranked by respondents.

\begin{tabular}{|c|c|c|c|c|}
\hline \multirow{2}{*}{ Defects } & \multicolumn{3}{|c|}{ Rank } & \multirow{2}{*}{ Index } \\
\hline & Rank 1 & Rank 2 & Rank 3 & \\
\hline Fly/knife cuts & 38 & 19 & 24 & 0.20 \\
\hline Flesh remnants on the skin & 26 & 15 & 21 & 0.14 \\
\hline Poor pattern & 15 & 9 & 19 & 0.09 \\
\hline Contamination with dirt & 21 & 13 & 18 & 0.13 \\
\hline Putrefaction/staling & 49 & 23 & 16 & 0.23 \\
\hline Scratches \& injuries & 11 & 7 & 25 & 0.08 \\
\hline Damaged by different diseases & 17 & 11 & 29 & 0.11 \\
\hline
\end{tabular}


different diseases, poor pattern and scratches and injuries were noted as less important causes for skin defects. Similar causes of skin defects were reported by [12] in different parts of Ethiopia. The focus group discussants revealed that the major problems in goat skin market structure were low access to skin market, lack of efficient transportation services, limited access to market information, poor infrastructure and lack of incentive to producers. These coupled with unfavorable climate contribute to the low quality of skins.

\subsection{Fattening Practices}

Most of the sample households practiced goat fattening with main target of fetching better prices during the holydays (Table 13). Across the study districts, young male (47.8\%), castrate (31.9\%), older male (13.0\%) and older female (7.2\%) were used for fattening. Females are less preferred for fattening compared to males and mainly used when they get older or are culled. The finding agrees with [43] who reported that females are fattened when they get older or when they cease giving birth. This point to the fact that females are kept for breeding to replace the flock. Majority of the respondents preferred local breeds for fattening due to its availability in large number and better adaptability to the local conditions.

The major criteria for selecting fattening goats were body conformation, health, physical characteristics, adaptation, age, availability and breed. The reason for using body confirmation by most farmers as a major characteristic of selecting goat for fattening may be related to the noticeable muscle development and fat deposition that make the finished goats attractive in the market. In agreement with the present results, body confirmation, age and physical characteristics were major features used to select small ruminant for fattening [13].

The major type of feed supplements for the fattening goats was whole grains (maize, sorghum and soybean), local brewery by-product, milling residues and household food leftovers.

The grains are boiled or roasted and salt added before offered to the goats. Blending of milling residues with salty water is also common. The mean length of fattening period is about $8.43 \pm 4.5$ month which seem to be longer indicating that the fattening practice is based on low quality feeds, traditional method and not strictly market oriented.

Table 13. Fattening of goats in the study districts.

\begin{tabular}{ccc}
\hline Criteria & Frequency $(\mathrm{N}=138)$ & Percent (\%) \\
\hline Conformation (height, length and appearance) & 63 & 45.6 \\
Physical characteristics (color, horn, etc.) & 18 & 13.0 \\
Health & 30 & 21.7 \\
Breed (indigenous) & 15 & 10.9 \\
\#Others & 12 & 8.7 \\
\hline
\end{tabular}

$\mathrm{N}=$ number of respondent; " encompass health, availability and adaptation. 


\section{Breeding Practices and Selection Criteria}

In all the study districts, uncontrolled natural mating is the dominant breeding practice where the breeding goats run together throughout the year (Table 14). The primary reason for uncontrolled mating might be due to herd grazing together in the communal grazing land (57.6\%), lack of awareness (29.4\%) and insufficient number of intact breeding males (13\%).

Majority of the breeding bucks were originated from their respective flocks and maintained in the same flocks for an average of three to four years. In this system, inbreeding could be a challenge resulting into poor fertility and growth rate. Similarly, in pastoral areas of Kenya, male goats were maintained in the flock for an average of 2 - 3 years [44]. Similar findings were also reported by [45].

Regardless of the uncontrolled mating, the focus group discussants identified two breeding seasons. As the main rainy season start, the annual grasses and vegetation rejuvenate very fast and goats get enough green feed from May to July, which initiate mating. Therefore, the major breeding seasons for goat flock are between May to July. The second breeding season was between Octobers to December.

Similarly, [46] reported that the natural environment governs the time of mating/kidding and it occurs with respect to the availability of feed. In contrast to the present finding, [4] reported that the major breeding seasons for goat flock was between November and January whereas the minor breeding season are April and June. In all the study districts, only $41.8 \%$ of the respondents owned one to two breeding bucks, the rest use neighbor and/or relatives for breeding purpose.

Table 14. Selection criteria for breeding buck and doe in the study areas as ranked by owners.

\begin{tabular}{|c|c|c|c|c|}
\hline \multirow{2}{*}{ Selection criteria } & \multicolumn{3}{|c|}{ Rank } & \multirow{2}{*}{ Index } \\
\hline & Rank 1 & Rank 2 & Rank 3 & \\
\hline \multicolumn{5}{|l|}{ Buck } \\
\hline Body size & 89 & 14 & 12 & 0.32 \\
\hline Growth rate & 24 & 81 & 11 & 0.25 \\
\hline Coat color & 6 & 9 & 17 & 0.09 \\
\hline Horn pattern & 0 & 8 & 20 & 0.05 \\
\hline Body conformation/appearance & 25 & 18 & 31 & 0.17 \\
\hline Age & 29 & 13 & 26 & 0.13 \\
\hline \multicolumn{5}{|l|}{ Doe } \\
\hline Body size & 101 & 15 & 13 & 0.33 \\
\hline Multiple births & 21 & 86 & 21 & 0.25 \\
\hline Milk yield & 27 & 26 & 84 & 0.21 \\
\hline Kidding interval & 15 & 8 & 10 & 0.07 \\
\hline Coat color & 0 & 20 & 18 & 0.06 \\
\hline Kid growth rate & 13 & 16 & 10 & 0.08 \\
\hline
\end{tabular}

Index $=\Sigma[3$ for rank $1+2$ for rank $2+1$ for rank 3$]$ for particular trait divided by $\Sigma[3$ for rank $1+2$ for rank $2+1$ for rank 3] for all traits. The highest index value indicates the highest importance of the trait. 
This finding is in line with previous findings [47]. This is because the majority of the households retain young male for castration and fattening, which implies that retention of young male for breeding is rarely practiced by owners. The selections of breeding animals were based on quantitative and qualitative traits. The selection criteria for breeding bucks and does were the same among the study districts. Majority (86.8\%) of the goat producers practice and distinguish the importance of selection based on their own selection criteria (Table 14).

Traits like body size, growth rate, body conformation (height, length and appearance) and coat color were considered as important traits and were given due emphasis in selecting breeding bucks. The preference of farmers for a particular coat color might be associated with social and cultural practices and market demand. The farmers focused on production traits to select a breeding doe in a flock. While the most important selection criterion for does was body size, prolificacy ability and milk yield.

Others like kidding interval, kid growth and coat color were also reported as selection criteria but with lower rankings. The present finding were in disagreement with earlier report [48] [49] who reported that about $90.8 \%$ of Short-eared Somali goat keepers in Dire Dawa select their breeding stock based on maternal history. In other study, [50] also indicated that both subjective and objective selection criteria are used with more emphasis placed on morphological traits of bucks. Large size animals were preferred as they provided higher milk yields, fetched better market prices, had better growth rates and reached market weights earlier.

\section{Production Constraints and Opportunities}

\subsection{Production Constraints}

The identification of major constraints for a given farm animal production system in a given area is a prerequisite to plan appropriate intervention strategies for improving productivity. The results showed that disease and parasite are ranked as first constraint in all the study districts (Table 15). The ranking of

Table 15. Major production constraints as ranked by households.

\begin{tabular}{ccccc}
\hline Constraints identified & \multicolumn{3}{c}{ Rank } & Index \\
\cline { 2 - 4 } Predators & Rank 1 & Rank 2 & Rank 3 & 0.45 \\
Disease and parasite & 145 & 16 & 14 & 0.09 \\
Inadequate vet. Services & 4 & 8 & 71 & 0.38 \\
Inadequate extension support & 25 & 153 & 19 & 0.01 \\
Market problem & 0 & 0 & 11 & 0.03 \\
Feed shortage & 3 & 0 & 25 & 0.006 \\
Absence of good management & 0 & 0 & 7 & 0.02 \\
\# Others & 0 & 0 & 17 & 0.01 \\
\hline
\end{tabular}

"encompasses labour, financial problem, theft and lack of improved breeds; Index $=\Sigma[3$ for rank $1+2$ for rank $2+1$ for rank 3] given for an individual constraint divided by $\Sigma[3$ for rank $1+2$ for rank $2+1$ for rank 3] summed for all constraints. 
disease and parasite as first constraint was in agreement with earlier reports [30] [51] [52]. Feed shortage problem was noted as low in all the study districts. This might be due to the availability of immense communal grazing land with abundant of vegetations (shrubs, bushes and grasses) throughout the year in the grazing land. The current result was in line with the finding of [19] who reported feed shortage problem to rank low. However, it is in disagreement with the reports of [53] who shows that feed shortage was very severe. Absence of good management and inadequate extension service was noted as less important constraints in all study districts. Labor shortage, theft and lack of appropriate breeds were also some of the challenges reported in the study districts. The above constraints were also mentioned during focus group discussion and key informants interview.

\subsection{Opportunities}

Despite the constraints, there are also quite favorable opportunities to increase goats' productivity in the study districts. The study districts possess large and genetically diverse livestock resources, which is not yet adequately exploited. Some of the breeds have special merits that meet the requirements of certain incentive markets and fetch high prices. The study districts are endowed with natural forests, various plant species, huge communal grazing land and high potential for growing crops that can be utilized as feed resources for goats. The agro-ecology of the region is conducive for the growth of various types of improved grasses, legumes and browse trees that favors goat production. There are many perennial rivers that can be used as a source of water for animals throughout the year. The sharing of international boundary with the Republic of Sudan grants unique opportunities to the region live animal trading across the border.

\section{Conclusion}

The farming system in the study districts is characterized by mixed crop-livestock production system and goats are kept under traditional extensive management system. The overall objectives for goat rearing across all the study districts were primarily for generating income, saving/insurance and meat for home consumption. Uncontrolled mating within the household flock was the common practice and bucks and does run together throughout the year. The major feed resources for goats include natural pasture, indigenous browse species, crop aftermath, whole grains, grain by-product and nonconventional feeds. Feed resource was not a limiting factor for goat production in the study districts. Disease is the primary constraint and farmers had veterinary access from government health posts. Hence, improved management system and disease control, breed improvement, and improved access to market opportunities are instrumental interventions to improve goat production system and thereby transform the system from traditional to market-oriented production. 


\section{Acknowledgements}

The authors are highly appreciated Ethiopian Agricultural Research Institute for funding the research work and Debre Zeit animal nutrition laboratory for their assistance in the laboratory analysis, the Ethiopian Leather Industry Development Institute (ELIDI) for accomplishing the leather quality analysis. We also acknowledge Pawe and Assosa Agricultural Research Centers and those who directly or indirectly contributed to the accomplishment of this study.

\section{Conflicts of Interest}

The authors declare no conflicts of interest regarding the publication of this paper.

\section{References}

[1] FARM-Africa (1996) Goat Types of Ethiopia and Eritrea. Physical Description and Management Systems. FARM-Africa, London, UK and International Livestock Research Institute, Nairobi, Kenya.

[2] CSA (Central Statistics Authority) (2018) Agricultural Sample Survey, 2017/18 (2010 E.C). Volume II, Report on Livestock and Livestock Characteristics (Private Peasant Holdings). Statistical Bulletin 587, Addis Ababa, Ethiopia.

[3] Ameha, S. (2008) Sheep and Goat Meat Characteristics and Goat Production Handbook for Ethiopia. Ethiopian Sheep and Goats Productivity Improvement Program (ESGPIP), Addis Ababa, 323-328.

[4] Tsedeke, K. (2007) Production and Marketing of Sheep and Goats in Alaba, SNNPR. Hawassa University. Awassa, Ethiopia.

[5] ESGPIP (Ethiopian Sheep and Goat Productivity Improvement Program) (2011) Export Requirements for Meat and Live Small Ruminants. Technical Bulletin No. 47.

[6] AsARC (Assosa Agricultural Research Center) (2006) Results of Farming System Survey in Benshangul Gumuz Regional State. Ethiopian Institute of Agricultural Research, Assosa Agricultural Research Center, Assosa, Ethiopia (Unpublished).

[7] Assosa Meteorological Station (2017) Climatic Data. Benishangul Gumuz Regional State of Ethiopia, Assosa Ethiopia.

[8] Getinet, A., Hedge, B.P., Bekele, T., Eniyew, N. and Workineh, A. (2005) Phenotypic Characterization of Goat Types in Northwestern Ethiopia. Ethiopian Journal of Animal Production, 5, 13-31.

[9] Yamane, T. (1967) Statistics, an Introductory Analysis. 2nd Edition, Harper and Row, New York.

[10] Kosgey, I.S. (2004) Breeding Objectives and Breeding Strategies for Small Ruminants in the Tropics. PhD Thesis, Wageningen University, the Netherlands, $272 \mathrm{p}$.

[11] ECSA and ORC Macro (2006) Ethiopia Demographic and Health Survey 2005. Ethiopian Central Statistical Agency, Addis Ababa, Ethiopia, and ORC Macro, Calverton, $\mathrm{MD}$.

[12] Dereje, T., Mengistu, U., Getachew, A. and Yoseph, M. (2014) Flock Structure, Level of Production, and Marketing of Three Ethiopian Goat Types Kept under Different Production Systems. Livestock Research for Rural Development, 26.

[13] Shenkute, B. (2009) Production and Marketing Systems of Small Ruminants in 
Gomma District of Jimma Zone, Western Ethiopia. M.Sc. Thesis. Hawasa University, Awassa, Ethiopia, 38-54.

[14] Mekuriaw, Y. and Asmare, B. (2014) Assessment of Pig Production and Constraints in Mecha District, Amhara Region, Northwestern Ethiopia. Advances in Agriculture, 2014, 1-5. https://doi.org/10.1155/2014/329254

[15] Bedasa, E., Amare, H. and Getachew, A. (2015) Variability of Feed Sources Availability and Their Managements in Mixed Crop-Livestock System: The Case of Three Watersheds in the Highlands of blue Nile Basin, Ethiopia. Global Journal of Animal Science, Livestock Production and Animal Breeding, 3, 235-242.

[16] FAO (2008) Country Report. FAO (Food and Agriculture Organization), Addis Ababa, Ethiopia.

[17] ILRI (International Livestock Research Institute) (2005) Metema Pilot Learning Site Diagnosis and Program Design. ILRI, Addis Ababa, Ethiopia.

[18] Tolera, A. and Abebe, A. (2007) Livestock Production in Pastoral and Agro-Pastoral Production Systems of Southern Ethiopia. Livestock Research for Rural Development, 19, 12. http://www.lrrd.org/lrrd19/12/tole19177.htm

[19] Tsegay, T. (2009) Characterization of Goat Production Systems and on-Farm Evaluation of the Growth Performance of Grazing Goats Supplemented with Different Protein Sources in Metema Woreda, Amhara Region, Ethiopia. Haramaya University, Haramaya, Ethiopia, 38-74.

[20] Hulunm, G. (2014) On-Farm Phenotypic Characterization and Performance Evaluation of Bati, Borena and Short Eared Somali Goat Populations of Ethiopia. Haramaya University, Haramaya.

[21] Solomon, A. (2014) Design of Community Based Breeding Programs for Two Indigenous Goat Breeds of Ethiopia. Doctoral Thesis, Vienna, Austria

[22] Dossa, L.H., Sangare, M., Buerkert, A. and Schlecht, E. (2015) Production Objectives and Breeding Practices of Urban Goat and Sheep Keepers in West Africa: Regional Analysis and Implications for the Development of Supportive Breeding Programs. SpringerPlus, 4, 281. https://doi.org/10.1186/s40064-015-1075-7

[23] Otieno, O.G., Junga, J.O., Badamana, M.S. and Amimo, J.O. (2015) Indigenous Knowledge Used in Breeding and Management of Capra Hircus Populations in Kajiado and Makueni Counties, Kenya. Open Journal of Genetics, 5, 111-135. https://doi.org/10.4236/ojgen.2015.53009

[24] Solomon, G., Azage, T., Berhanu, G. and Dirk, H. (2010) Sheep and Goat Production and Marketing Systems in Ethiopia: Characteristics and Strategies for Improvement. Improving Productivity and Market Success (IPMS) of Ethiopian Farmers Project, International Livestock Research Institute (ILRI), Addis Ababa, Ethiopia.

[25] Mekuiraw, S., Mekuiraw, Z., Taye, M., Yitayew, A., Assefa, H. and Haila., A. (2012) Traditional System and Farmers' Perception on Local Sheep Breeds (Washera and Farta) and Their Crosses in Amhara Regionl, Ethiopia. Livestock Research for Rural Development, 24. http://www.|rrd.org//rrd24/1/meku24004.htm

[26] Gebeyehu, A., Hundessa, F., Umeta, G., Muleta, M. and Debela, G. (2013) Assessment on Challenges and Opportunities of Goat Farming System in Adami Tulu, Arsi Negelle and Fantala Districts of Oromia Regional State, Ethiopia. African Journal of Agricultural Research, 8, 26-31.

[27] Yeshitila, A. (2007) Efficiency of Livestock Feed Resources Utilization and Forage Development in Alaba Woreda, Southern Ethiopia. Haramaya University, Haramaya, Ethiopia. 
[28] Bimrew, A. (2016) Evaluation of the Agronomic, Utilization, Nutritive and Feeding Value of Desho Grass (Pennisetum Pedicellatum). Jimma University, Jimma.

[29] Shenkute, B., Legasse, G., Tegegne, A. and Hassen, A. (2010) Small Ruminant Production in Coffee-Based Mixed Crop-Livestock System of Western Ethiopian Highlands: Status and Prospectus for Improvement. Livestock Research for Rural Development, 22. http://www.lrrd.org/lrrd22/10/shen22186.htm

[30] Fikru, S. and Gebeyew, K. (2015) Sheep and Goat Production Systems in Degehabur Zone, Eastern Ethiopia: Challenge and Opportunities. Advances in Dairy Research, 3, 134.

[31] Alemu, A. (2015) On-Farm Phenotypic Characterization and Performance Evaluation of Abergelle and Central Highland Goat Breeds as an Input for Designing Community-Based Breeding Program. Haramaya University, Haramaya, Ethiopia, 147.

[32] Neme, Y., Ahmed, M. and Duguma, G. (2017) Socio-Economic Characteristics of Households and Small Ruminant Marketing System in Ada Barga and Ejere Districts of West Shoa Zone, Oromia, Ethiopia. Proceeding of the 25th Annual Conference of the Ethiopian Society of Animal Production (ESAP), Haramaye University, Haramaya, 24-26 August 2017.

[33] Tsegaye, D., Belay, B. and Haile, A. (2013) Prevalence of Major Goat Diseases and Mortality of Goat in Daro-Labu District of West Hararghe. Ethiopian Journal of Education and Sciences, 2, 665-672.

[34] Abebe, Y. (2010) Assessment of Small Ruminant Production Systems and on-Farm Evaluation of Urea Treated Wheat Straw and Concentrate Feeding on Sheep Body Weight Change in Burie Woreda, West Gojjam. Haramaya University, Haramaya.

[35] Workneh, A. and Rowlands, J. (2004) Design, Execution and Analysis of the Livestock Breed Survey in Oromiya Regional State, Ethiopia. OADB, Addis Ababa, Ethiopia, and ILRI, Nairobi, Kenya, 260 p.

[36] Woldu, T., Dadi, H., Guru, M. and Gelashe, D. (2004) Productivity of Arsi-Bale Goat Types under Farmers' Management Condition: A Case of Arsi Negelle. Proceedings of the 13 th Annual Conference of the Ethiopian Society of Animal Production (ESAP), Addis Ababa, Ethiopia, 25-27 August 2004, 67-71.

[37] Jemal, G. (2008) Phenotypic Characterization and Performance Evaluation of Abergelle Goat under Traditional Management System in Tanqua-Abergelle District of Tigray, Ethiopia. Mekelle University, Mekelle, Ethiopia.

[38] Ebrahim, A. and Hailemichael, A. (2012) Sheep and Goat Production and Utilization in Different Agro-Ecological Zones in Tigray, Ethiopia. Livestock Research for Rural Development, 24. http://www.lrrd.org/lrrd24/1/asse24016.htm

[39] Derebe, B. (2008) Growth, Reproductive Performance and Carcass Characteristics of Abergelle and Central Highland Goat Types under Traditional and Slightly Improved Management in Sekota Woreda. Haramaya University, Haramaya, 77.

[40] Assefa, E. (2007) Assessment on Production System and Marketing of Goats at Dale District (Sidama Zone). University of Hawassa, Hwassa, Ethiopia.

[41] Tsegaye, D. (2011) Herd Husbandry and Breeding Practices of Goat in Different Agro-Ecologies of Western Hararghe, Ethiopia. Jimma, Ethiopia.

[42] Tsegaye, D. and Lemma, T. (2009) Livestock Production Systems in Darolabu, Habro and Boke Districts ofwestern Harerghe. Proceedings of the 16th Annual Conference of the Ethiopian Society of Animal Production (ESAP), Addis Ababa, Ethiopia, 8-10 October 2008. 
[43] Ahmed, T.M., Hashem, A., Khan, M., Rahman, M.F. and Hossain, M. (2010) Factors Related to Small Scale Cattle Fattening in Rural Areas of Banladesh. Journal of Animal Science, 39, 116-124. https://doi.org/10.3329/bjas.v39i1-2.9684

[44] Kosgey, I.S., Rowlands, G.J., van Arendonk, J.A.M. and Baker, R.L. (2008) Successes and Failures of Small Ruminant Breeding Programmes in the Tropics: A Review. Small Ruminant Research, 77, 11-24.

https://doi.org/10.1016/j.smallrumres.2008.02.005

[45] Saico, S. and Abul, S. (2007) Socio-Economic Constraints on Goat Farming in the Lowveld of Swaziland. Journal of Sustainable Development in Africa, 9, 37-49.

[46] Solomon, G., Komen, H., Hanote, K.S., Aynalem, H.M. and Tadelle, D. (2011) Characterization and Conservation of Indigenous Sheep Genetic Resources: A Practical Framework for Developing Countries. ILRI Research Report No. 27, Nairobi, Kenya.

[47] Abraham, H., Gizaw, S. and Urge, M. (2017) Begait Goat Production Systems and Breeding Practices in Western Tigray, North Ethiopia. Open Journal of Animal Sciences, 7, 198-212. https://doi.org/10.4236/ojas.2017.72016

[48] Gebreyesus, G. (2010) Community Based Participatory Characterization of the Short-Eared Somali Goat Population around Dire Dawa.

[49] Misbah, F. (2013) Community-Based Characterization of Afar Goat Breeds around Aysaita District of Afar Region. Jimma University, Jimma, Ethiopia.

[50] Tesfaye, K., Aynalem, H. and Hailu, D. (2012) Smallholder Goat Breeding and Flock Management Practices in the Central Rift Valley of Ethiopia. Tropical Animal Health and Production, 44, 999-1006. https://doi.org/10.1007/s11250-011-0033-9

[51] Girma, D., Mieso, G., Feyisa, H. and Misgana, D. (2013) Assessment of Farmers' Management Practices and Factors Affecting Goats' Production System in Adami Tulu Jido kombolcha District of East Shawa Zone, Ethiopia. Agriculture and Biology Journal of North America, 4, 520-526.

[52] Sissay, M.M., Asefa, A., Uggla, A. and Waller, P.J. (2006) Anthelmintic Resistance of Nematode Parasites of Small Ruminants in Eastern Ethiopia: Exploitation of Refugia to Restore Anthelmintic Efficacy. Veterinary Parasitology, 135, 337-346. https://doi.org/10.1016/j.vetpar.2005.09.005

[53] Abebe, Y., Melaku, S. and Tegegne, A. (2013) Assessment of Sheep Marketing System in Burie District, North Western Ethiopia. Wudpecker Journal of Agricultural Research, 2, 97-102. 